\title{
Increased spring freezing vulnerability for alpine shrubs under early snowmelt
}

\author{
J. A. Wheeler · G. Hoch • A. J. Cortés · J. Sedlacek • \\ S. Wipf · C. Rixen
}

Received: 29 May 2013 / Accepted: 20 December 2013 / Published online: 17 January 2014

(C) Springer-Verlag Berlin Heidelberg 2014

\begin{abstract}
Alpine dwarf shrub communities are phenologically linked with snowmelt timing, so early spring exposure may increase risk of freezing damage during early development, and consequently reduce seasonal growth. We examined whether environmental factors (duration of snow cover, elevation) influenced size and the vulnerability of shrubs to spring freezing along elevational gradients and snow microhabitats by modelling the past frequency of spring freezing events. We sampled biomass and measured the size of Salix herbacea, Vaccinium myrtillus, Vaccinium uliginosum and Loiseleuria procumbens in late spring. Leaves were exposed to freezing temperatures to determine the temperature at which $50 \%$ of specimens are killed for each species and sampling site. By linking site snowmelt and temperatures to long-term climate measurements, we extrapolated the frequency of spring freezing events at each
\end{abstract}

Communicated by Kouki Hikosaka.

Electronic supplementary material The online version of this article (doi:10.1007/s00442-013-2872-8) contains supplementary material, which is available to authorized users.

J. A. Wheeler $(\bowtie) \cdot$ S. Wipf · C. Rixen

WSL Institute for Snow and Avalanche Research SLF,

7260 Davos, Switzerland

e-mail: julia.wheeler@slf.ch

J. A. Wheeler · G. Hoch

Institute of Botany, University of Basel, 4056 Basel, Switzerland

\section{A. J. Cortés}

Evolutionary Biology Centre, University of Uppsala,

75236 Uppsala, Sweden

J. Sedlacek

Department of Biology, University of Konstanz,

78457 Constance, Germany elevation, snow microhabitat and per species over 37 years. Snowmelt timing was significantly driven by microhabitat effects, but was independent of elevation. Shrub growth was neither enhanced nor reduced by earlier snowmelt, but decreased with elevation. Freezing resistance was strongly species dependent, and did not differ along the elevation or snowmelt gradient. Microclimate extrapolation suggested that potentially lethal freezing events (in May and June) occurred for three of the four species examined. Freezing events never occurred on late snow beds, and increased in frequency with earlier snowmelt and higher elevation. Extrapolated freezing events showed a slight, non-significant increase over the 37-year record. We suggest that earlier snowmelt does not enhance growth in four dominant alpine shrubs, but increases the risk of lethal spring freezing exposure for less freezing-resistant species.

Keywords Climate change - Advanced snowmelt . Growth $\cdot$ Spring freezing resistance $\cdot$ Alpine dwarf shrubs

\section{Introduction}

Warming air temperatures due to climate change triggering reduced snowfall and earlier snowmelt have been documented in many alpine systems (IPCC 2007; Rixen et al. 2012). Early snowmelt potentially represents a radical environmental change for many alpine plant communities, the phenology of which may be strongly linked with snowmelt timing in the spring (Keller and Körner 2003; Wipf and Rixen 2010). Dwarf shrubs represent a dominant vegetation type in the alpine zone above the tree line, but despite increasing evidence for earlier snowmelt in alpine systems, the response of these communities to climate-induced changes in snowmelt timing 
has rarely been studied (Wipf and Rixen 2010; but see Wipf et al. 2009).

In alpine environments, a longer, warmer growing season might be associated with enhanced plant growth. This has been observed in Arctic shrub species, which have shown vegetative size and productivity increases with warming (e.g. Hudson et al. 2011; Elmendorf et al. 2012), indicating that vegetative size is a practical field measure for plant response to environmental change. However, accelerated alpine spring snowmelt is a critical ecosystem change: it can increase the length of the photosynthetic period, increase drought exposure, alter timing of early season phenology and, perhaps most importantly, increase exposure to spring freezing events (Inouye 2008). The few studies available examining alpine shrub response to accelerated snowmelt suggest growth is typically not enhanced under early snowmelt in temperate alpine habitats (Wipf et al. 2009; Rixen et al. 2010; Gerdol et al. 2013). Increased exposure to freezing events, as driven by earlier snowmelt timing, has also been shown to increase bud damage in alpine wildflowers (Inouye 2008), damage leaves and apical buds of alpine shrubs Vaccinium spp. and Empetrum hermaphroditum (Rixen et al. 2012), and reduce leaf expansion, flowering and fruiting in Vaccinium myrtillus (Bokhorst et al. 2008; Gerdol et al. 2013).

Naturally occurring spring and summer freezing events are episodic in alpine zones, and can reduce growth through the decrease of available metabolic energy, the reduction of water/nutrient uptake, and the damage/dieoff of leaf tissue (Larcher et al. 2003; Rixen et al. 2012). Spring freezing rarely kills alpine plants, but these cold events have been shown to significantly reduce both above-ground biomass and reproductive output, and can potentially reduce the abundance and competitive ability of the species at the population level (Molau 1997; Bokhorst et al. 2008). Some alpine plants may delay spring phenology until the risk of freezing damage to sensitive new tissue has passed (Körner 2003), but since this strategy is most likely controlled by photoperiodism, it probably does not occur in alpine sites, as day length at time of snowmelt is already near its annual maximum [a 15-h day-length threshold has been suggested for the onset of alpine plant growth (Heide 2001)]. Freezing resistance differs strongly between species and functional groups, and has been extensively studied previously, with many studies also including alpine shrubs (e.g. Sakai and Larcher 1987; Taschler and Neuner 2004; Martin et al. 2010). However, while studies have examined freezing resistance along elevational gradients (Taschler and Neuner 2004; SierraAlmeida et al. 2009), soil warming gradients (Martin et al. 2010), and between snow microhabitats (Bannister et al. 2005), to our knowledge no one has examined the same species along elevation and snowmelt gradients within a single study. Wipf et al. (2009) examined the impacts of accelerated snowmelt on growth and phenology in alpine shrubs and speculated about the role of spring frosts in alpine shrub failure to respond positively to longer seasons, but did not quantify shrub freezing resistance, or examine the long-term frequency of spring freezing events or community response along the elevational gradient. In complex alpine ecosystems, it is critical to understand the interplay between ongoing changes in elevational temperature gradients, snowmelt effects as controlled by microtopography, and species-specific freezing resistance responses in order to predict the effects of earlier spring snowmelt on alpine shrubs.

In this study, we investigated the impact of growing season length (triggered by natural snowmelt timing) and elevation on shrub growth and risk of exposure to potentially lethal spring and early summer freezing events in four alpine dwarf shrubs. We hypothesized that earlier snowmelt does not enhance shrub performance because it increases the risk of exposure to damaging spring freezing events, thus it fails to enhance or even reduces seasonal growth. We sampled shrub biomass with mature leaf tissue along an elevational and snowmelt gradient and exposed it to simulated freezing conditions in order to:

1. Assess environmental factors (duration of snow cover, elevation) influencing functional growth traits (leaf area, annual shoot increment, stem length).

2. Compare interspecific and intraspecific freezing resistance [measured as the temperature at which $50 \%$ of specimens are killed (LT-50)] along the elevational and snowmelt gradients.

3. Determine the potential vulnerability of mature leaf tissue in shrubs to post-snowmelt freezing along the elevational and snowmelt gradients through the frequency of species-specific spring lethal freezing events by using long-term meteorological data.

The results of this experiment will add to our understanding of alpine shrub responses to accelerated snowmelt, and aid in predicting potential changes in the shrub community driven by climate warming.

\section{Materials and methods}

Study site and sampling design

Our study transect is located on the northeast-exposed face of the Jakobshorn peak (2,590 $\mathrm{m}$ a.s.l.), above the Stillberg Long-Term Afforestation Research Area $\left(9^{\circ} 52^{\prime} \mathrm{E}, 46^{\circ} 46^{\prime} \mathrm{N}\right)$ in the central Alps, Switzerland. The transect covers an elevational gradient of 2,100-2,500 $\mathrm{m}$ a.s.l., from just above 
the natural climatic tree line to the peak. The climate record at $2,100 \mathrm{~m}$ a.s.l. (1975 to present) shows annual mean precipitation at $1,150 \mathrm{~mm}$, with $48 \%$ falling between June and September. Snowfall can occur in all months, with continuous snow cover occurring usually from mid-October to late May (Wipf et al. 2009). Mean spring air temperatures (May $=4.5{ }^{\circ} \mathrm{C}$, June $=7.2{ }^{\circ} \mathrm{C}$ ) gradually warm to summer mean temperature peaks (July $=10.0{ }^{\circ} \mathrm{C}$, August $=9.8{ }^{\circ} \mathrm{C}$ ), with only episodic freezing events between May and September. The 37-year climatic record at this site indicates that mean June-July-August air temperatures have warmed significantly, and that snow is melting significantly earlier in the spring, at a rate of 3.5 days per decade (Rixen et al. 2012).

Sites were established at four elevations along the 400-m gradient, at an early exposure ridge and a late snow bed microhabitat, for a total of eight sites (Table 1). Relatively early melting snow bed sites were paired with very early exposure ridges in order to ensure that sampled shrubs would have developed to similar leaf phenophases. In situ soil temperature loggers (iButton; Maxim Integrated, San Jose) recorded 2012 soil temperatures (2-h intervals) at each site at $5-\mathrm{cm}$ soil depth and were used in conjunction with field observation to determine day of snowmelt (date in spring when soil temperature rose abruptly from the near $0{ }^{\circ} \mathrm{C}$ characteristic of snow cover). Growing degree days (GDD; sum of daily mean temperatures above $5{ }^{\circ} \mathrm{C}$ ) were calculated from snowmelt to the end of August for each site. Total season length for each site was calculated from snowmelt day to first day in autumn when mean air temperatures fell below $0{ }^{\circ} \mathrm{C}$.

Four common and dominant alpine dwarf shrub species (two to three specimens per site) were sampled at each site for this study: evergreen Loiseleuria procumbens (L.) Desv., family Ericaceae, and deciduous shrubs Vaccinium myrtillus L., family Ericaceae, Vaccinium uliginosum L. ssp. gaultherioides, family Ericaceae and

Table 1 Elevation and snowmelt day of paired ridge $(R ; n=4)$ and snow bed $(S ; n=4)$ sampling sites and average daily minimum, maximum, and mean air temperatures (temp.; ${ }^{\circ} \mathrm{C}$ at $2 \mathrm{~m}$ ) during the 7-day period prior to biomass sampling (16-23 June 2012)

\begin{tabular}{|c|c|c|c|c|}
\hline & Low & $\begin{array}{l}\text { Low- } \\
\text { intermediate }\end{array}$ & $\begin{array}{l}\text { High- } \\
\text { intermediate }\end{array}$ & High \\
\hline Elevation (m) & 2,109 & 2,260 & 2,372 & 2,510 \\
\hline $\begin{array}{l}\text { Snowmelt } \\
\text { (day of year) }\end{array}$ & $\begin{array}{l}R=148 \\
S=162\end{array}$ & $\begin{array}{l}R=132 \\
S=145\end{array}$ & $\begin{array}{l}R=158 \\
S=170\end{array}$ & $\begin{array}{l}\mathrm{R}=130 \\
\mathrm{~S}=159\end{array}$ \\
\hline $\begin{array}{l}\text { Minimum } \\
\text { temp. }\left({ }^{\circ} \mathrm{C}\right)\end{array}$ & 8.71 & 7.74 & 7.04 & 6.14 \\
\hline $\begin{array}{l}\text { Maximum } \\
\text { temp. }\left({ }^{\circ} \mathrm{C}\right)\end{array}$ & 18.23 & 17.26 & 16.56 & 15.66 \\
\hline Mean temp. $\left({ }^{\circ} \mathrm{C}\right)$ & 13.10 & 12.13 & 11.43 & 10.53 \\
\hline
\end{tabular}

Salix herbacea L., family Salicaceae. Shrub stem and leaf biomass were sampled during a 1-day period on 23 June 2012 at similar phenological stages (mature, newly opened leaves) to minimize potential intraspecies differences in LT-50. The 1-day sampling can only be considered a snapshot of LT-50 because cold hardiness continuously changes through plant life stages (Sakai and Larcher 1987). However, our sampling period was ideal for our purposes because leaves were already fully developed but without signs of damage like herbivory or senescence yet; such conditions were necessary to cover our research design including the gradients in elevation and snowmelt. Furthermore, air temperatures in the 7 days prior to sampling (Table 1) were never below $0{ }^{\circ} \mathrm{C}$, making it unlikely that the sampled shrubs were unusually cold-hardened. Functional growth traits (mean leaf area calculated from leaf length $\times$ leaf width, mean stem length) were measured and used as the primary growth variables.

\section{Freezing resistance (LT-50) determination}

Live shrub biomass (stems and leaves) was immediately placed in cooling boxes after sampling and transported to the freezing lab facility at the University of Basel (Basel, Switzerland) within a day. Specimen biomass samples (from six to eight branches with intact, healthy leaves) were separated into nine subsamples, then wrapped in paper and aluminium foil to buffer temperature fluctuations [effective to $0.1 \mathrm{~K}$ (Larcher et al. 2010)] and to prevent water loss and mechanical damage. Each subsample was exposed to minimum temperature treatments $\left(4{ }^{\circ} \mathrm{C},-2{ }^{\circ} \mathrm{C},-4{ }^{\circ} \mathrm{C}\right.$, $\left.-7{ }^{\circ} \mathrm{C},-11{ }^{\circ} \mathrm{C},-14{ }^{\circ} \mathrm{C},-16{ }^{\circ} \mathrm{C},-19{ }^{\circ} \mathrm{C},-20{ }^{\circ} \mathrm{C}\right)$ in a computer-controlled freezing system, where temperature was started at $4{ }^{\circ} \mathrm{C}$, decreased to the minimum temperature at $3 \mathrm{~K} \mathrm{~h}^{-1}$, maintained for $4 \mathrm{~h}$, and then returned to $4{ }^{\circ} \mathrm{C}$ at $3 \mathrm{~K} \mathrm{~h}^{-1}$. Damage to leaf tissue was visually quantified on a $10 \%$ scale $(0-100 \%$ damage) to determine the lethal kill temperature for mature leaf tissue in each specimen, with damage to $>70 \%$ of the leaves classified as a 'kill'. Visual quantification of damage (surface darkening and limpness from loss of turgor pressure) for these species is strongly correlated with leaf tissue electrolyte leakage associated with freezing damage (Martin et al. 2010). LT-50 for each specimen was determined by fitting a sigmoid curve to the eight points on the temperature-percent damage plot and calculating the inflection point (Martin et al. 2010). If the sigmoid curve lacked a defined inflection point, the LT-50 for that specimen was not included in the analysis; however, this was relatively infrequent $(<10 \%$ of the data points). Data were pooled by species for each site, and LT50 was then calculated for each species at each sampling site. 


\section{Lethal spring cold events}

Lethal spring freezing events were defined as spring (May and June) daily air temperature minima either at or below the mean LT-50 for a shrub species occurring a minimum of 5 days after projected site snowmelt at 40 microsites (20 ridges, 20 snow beds) along the elevational gradient (sites separated by a mean elevational distance of approximately $50 \mathrm{~m}$ ). The minimum 5-day threshold after projected snowmelt date was implemented in order to maximize the probability of shrubs having undergone bud break prior to a freezing event occurring. The in situ climate station at 2,100 $\mathrm{m}$ a.s.l. recorded hourly air temperature $(2 \mathrm{~m})$ and annual date of snowmelt from 1975 to 2012. Snowmelt dates measured at each of the 20 sites in 2012 were used to relate snowmelt date at a given site to the date recorded at the climate station. Snowmelt dates in 2012 were representative of the long-term mean in the region (1 day later than the 37-year mean). Nearby snow depth accumulations have been shown to be similar from year to year (Schirmer et al. 2011), and the order of site emergence from snow has been relatively consistent over 2 years of monitoring (2011-2012; J. A. Wheeler, unpublished data). This relative snowmelt date for each site was then used to estimate date of snowmelt for all transect sites between 1975 and 2012. Site air temperatures after predicted snowmelt were extrapolated for each site using a lapse rate of $0.52 \mathrm{~K}_{100 \mathrm{~m}^{-1}}$ [averaged from long-term May-June data at $n=15$ climate stations in Swiss Alps (Kollas 2013)]. This lapse rate value is generally similar to those calculated for long-term daily temperature minima under a range of alpine atmospheric conditions in spring months (Kirchner et al. 2013). Frequency and yearly recurrence of lethal spring freezing events were then calculated for each species at each site for the past 37 years in order to extrapolate relative spring freezing event frequency along the elevational and snowmelt gradients, and over multiple decades. Since snowmelt day for each site over the long-term record is extrapolated from the 2012 record and not determined from site observation, this is meant as an indicator of relative changes of freezing frequency along the gradients, and not a direct prediction of the actual (absolute) freezing frequency.

\section{Statistical analyses}

To quantify environmental differences along the elevational gradient and between snow microhabitats, we used general linear models to analyse both snowmelt timing and soil temperatures (response variables) along the elevational gradient and between microhabitat types (explanatory variables). Growing season soil temperature was significantly negatively correlated with elevation and with earlier snowmelt day, and demonstrated similar trends as the results for elevation in the individual linear regressions; as elevational trends were slightly stronger, elevation was chosen as the explanatory variable and soil temperature was dropped from the analysis. We used general linear models (type 3 error) to analyse growth traits (mean leaf area, mean stem length) for each species individually, with elevation and snowmelt day as explanatory variables. We analysed freezing resistance (LT-50) also with general linear models but with species, elevation and snowmelt day as explanatory variables. Because species was highly significant, we also analysed freezing resistance on a species basis similar to the growth traits. Mean leaf area and mean stem length were log-transformed to ensure normality. Assumptions of linearity and homoscedasticity were confirmed using standard diagnostic plots. We used generalized linear models (quasi-Poisson distribution) to analyse the frequency of spring freezing events for each species over the 37-year record, with centred elevation and centred snowmelt day as explanatory variables. However, results are only shown for $V$. myrtillus, since it was the only species exposed to relatively frequent spring freezing events all along the elevational gradient. All analyses were carried out in R version 2.15.1.

\section{Results}

Snowmelt and elevation

Snowmelt timing (Table 1) was typical for the long-term average in 2012, occurring 1 day later than the long-term mean (data not shown). Snowmelt occurred significantly earlier on ridges $(n=4)$ relative to snow bed microhabitats $[n=4$; mean ridge snowmelt day of year $(\mathrm{DOY})=142$, mean snow bed snowmelt DOY $=159, F=20.1$, $p<0.0001$ ]; however, elevation had no significant effect on snowmelt timing $(F=0.24, p=0.62)$; this indicates that local microhabitat effects are the primary driver of snowmelt timing. These strong local effects may be characteristic at the landscape scale, as two similar transects on other mountains nearby also failed to demonstrate consistent elevational-snowmelt effects over multiple years (data not shown). We assumed that growing season ended on 14 September for all sites, when daily mean air temperature fell to $-1.36^{\circ} \mathrm{C}$ at $2,090 \mathrm{~m}$ a.s.l. Hence, the mean ridge growing season length was 116 days, while mean snow bed growing season length was 99 days. The 17-day difference between ridge and snow bed meltout timing represents about $17 \%$ of the mean growing season length at snow bed sites.

Ridge and snow bed microhabitats significantly differed in soil temperature after snowmelt in June, but these differences disappeared over the course of the growing season; June GDD significantly increased with earlier snowmelt 
day (mean ridge June GDD $=278$, mean snow bed June $\mathrm{GDD}=214 ; F=17.8, p=0.0002)$, but this difference between microhabitat types was not present over the course of the entire summer, as growing season GDD (snowmelt to the end of August) was not significantly different (mean ridge $\mathrm{GDD}=1,202$, mean snow bed $\mathrm{GDD}=1,077$; $F=1.2, p=0.26)$. Mean June temperatures were not significantly different (mean ridge June $=10.0{ }^{\circ} \mathrm{C}$, mean snow bed June $=9.85{ }^{\circ} \mathrm{C} ; F=1.7, p=0.20$ ), while mean soil temperatures over the entire growing season were significantly higher at later snowmelt sites (mean ridge $=10.0{ }^{\circ} \mathrm{C}$, mean snow bed $=10.4{ }^{\circ} \mathrm{C} ; F=13.2$, $p=0.001)$.

June GDD and growing season GDD decreased with marginal significance along the elevational gradient $(t=-1.96, r=-0.34, p=0.059$ for June GDD; $t=-1.84, r=-0.32, p=0.075$ for season GDD) while mean June and mean growing season temperature both decreased significantly elevationally $(t=-5.17$, $r=-0.69, p<0.0001$ for mean June temperature; $t=-2.49, r=-0.41, p=0.018$ for mean season temperature).

Growth performance along environmental gradients

The prostrate shrubs $S$. herbacea and L. procumbens showed no elevational growth response (Figs. 1, 2). However, the higher statured V. myrtillus and V. uliginosum both demonstrated a significant negative growth response to elevation, with a significant decrease in mature leaf area with increasing elevation (Fig. $1 ; d f=1, F=22.42, p=0.0032$; $d f=1, F=12.74, p=.012) . V$. uliginosum, the tallest shrub in this study, further demonstrated a significant decrease in mean stem length with elevation (Fig. $2 ; d f=1$, $F=14.82, p=0.0085$ ). No shrub species demonstrated a significant growth response to snowmelt timing. This suggests that differences in snowmelt and growing season length in the observed range have a much weaker effect on shrub growth performance than other environmental drivers (e.g. elevation).
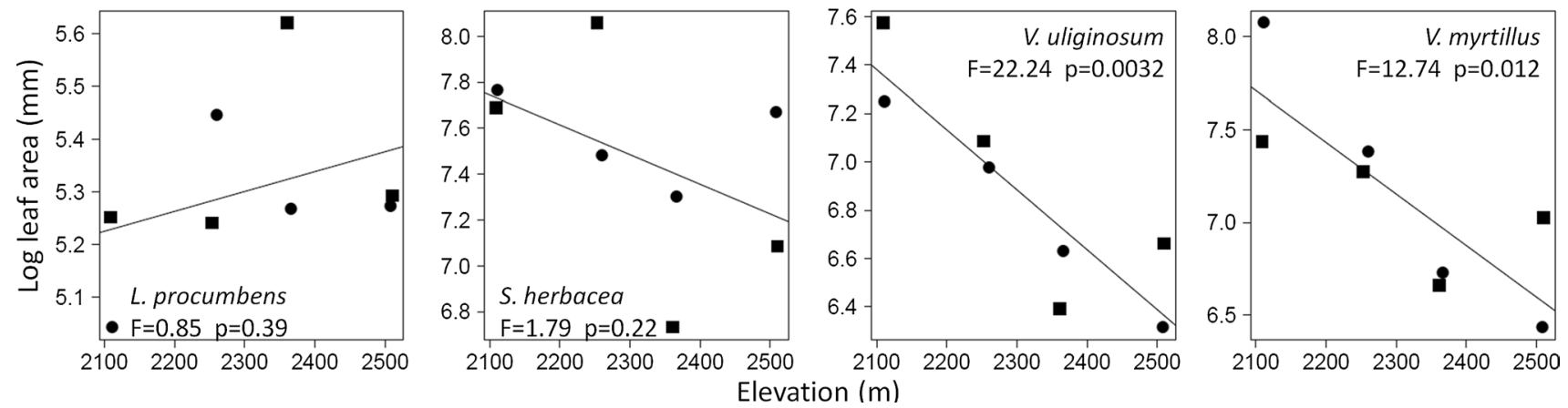

Fig. 1 Mean leaf area along elevational gradient in Loiseleuria procumbens, Salix herbacea, Vaccinium uliginosum and Vaccinium myrtillus. Squares represent ridges and circles represent snow bed microhabitats. $F$ - and $p$-values refer to the linear regressions for each species (black line). Note log scale used on $y$-axis and different $y$-axes for the different species
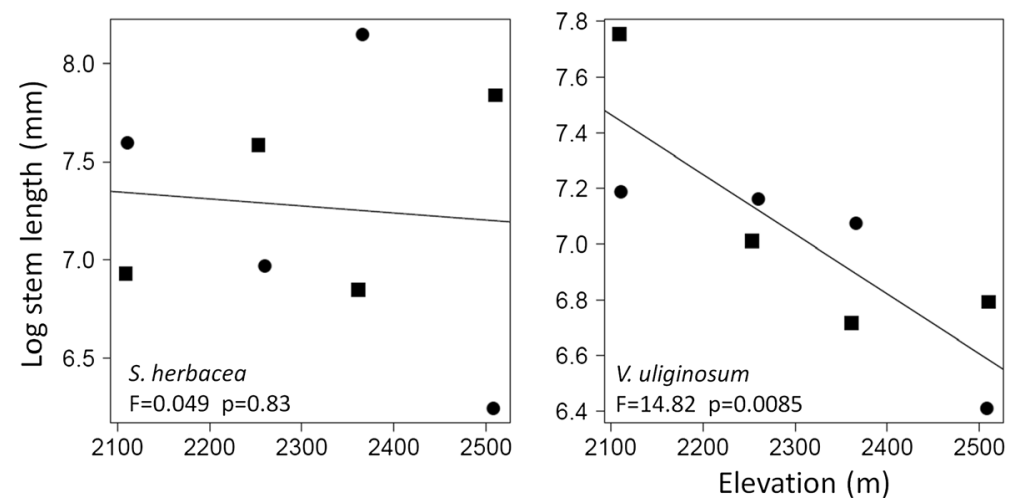

Fig. 2 Mean stem length along elevational gradient in $S$. herbacea, $V$. uliginosum and V. myrtillus. Squares represent ridges and circles represent snow bed microhabitats. Stem length excluded for $L$. procumbens due to uncertainty in determining total stem length in samples.
$F$ - and $p$-values refer to the linear regressions for each species (black line). Note $\log$ scale used on $y$-axis and the different $y$-axes for the different species 
Vulnerability to spring freezing damage

Pooled spring freezing resistance (LT-50) of leaves was significantly different between species $(d f=3, F=22.34$, $p<0.0001$ ), with low-stature evergreen $L$. procumbens having the highest freezing resistance $\left(n=8,-11.0^{\circ} \mathrm{C}\right)$, followed by $V$. uliginosum $\left(n=8,-9.0{ }^{\circ} \mathrm{C}\right)$, S. herbacea $\left(n=8,-7.0^{\circ} \mathrm{C}\right)$ and $V$. myrtillus $\left(n=8,-5.1^{\circ} \mathrm{C}\right)$. Spring freezing resistance was not found to be significantly different along the elevational and snowmelt gradients in any shrub species (Fig. 3; elevation gradient $L$. procumbens $d f=1$, $F=1.11, p=0.33 ;$ S. herbacea $d f=1, F=0.92, p=0.38$; $V$. uliginosum $d f=1, F=0.17, p=0.70 ; V$. myrtillus $d f=1$, $F=1.62, p=0.25$; snowmelt gradient $L$. procumbens $d f=1, F=0.066, p=0.81 ; S$. herbacea $d f=1, F=1.31$, $p=0.30 ; V$. uliginosum $d f=1, F=0.0024, p=0.96 ; V$. myrtillus $d f=1, F=1.21, p=0.32$ ). This may indicate species-specific (i.e. genotypic) freezing resistance, as opposed to an environmentally driven effect (i.e. phenotypic), specifically in mature leaf tissue.

Based on our extrapolations, no lethal cold events occurred in July between 1975 and 2012 for any species, indicating leaf-damaging cold events are primarily a spring (May-June) phenomenon. Supplemental Figure 1 demonstrates spring (May-June) temperature minima over 37 years, which we used to extrapolate the frequency of lethal spring cold events after snowmelt occurring at or below species LT-50 thresholds. Lethal spring events did not occur on snow beds and thus lethal-event frequency analyses were restricted to ridge microhabitats. No lethal spring cold events were documented on the exposed ridges for $L$. procumbens in the 37-year temperature record. Spring lethal cold events for $V$. uliginosum were extremely rare and were only detected in 2012 (the last year on record). Lethal cold events for $S$. herbacea occurred at a significantly lower frequency than for $V$. myrtillus on the 20 exposed ridges over the 37-year temperature record ( $V$. myrtillus total $n$ events $=375, S$. herbacea total $n$ events $=75, d f=1$, $F=40.08, p<0.0001)$. S. herbacea lethal freezing events were also generally restricted to the highest elevational sites, while $V$. myrtillus experienced lethal freezing at all elevations. Because damaging spring freezing events were relatively abundant for $V$. myrtillus only, we restricted the statistical analyses of temporal and spatial occurrences of freezing events to this species.

Lethal spring cold events in V. myrtillus on the spatial and temporal scale

The frequency of lethal spring cold events on exposed ridges was stable over the 37-year record, and even demonstrated a slight increase, although the increase was not
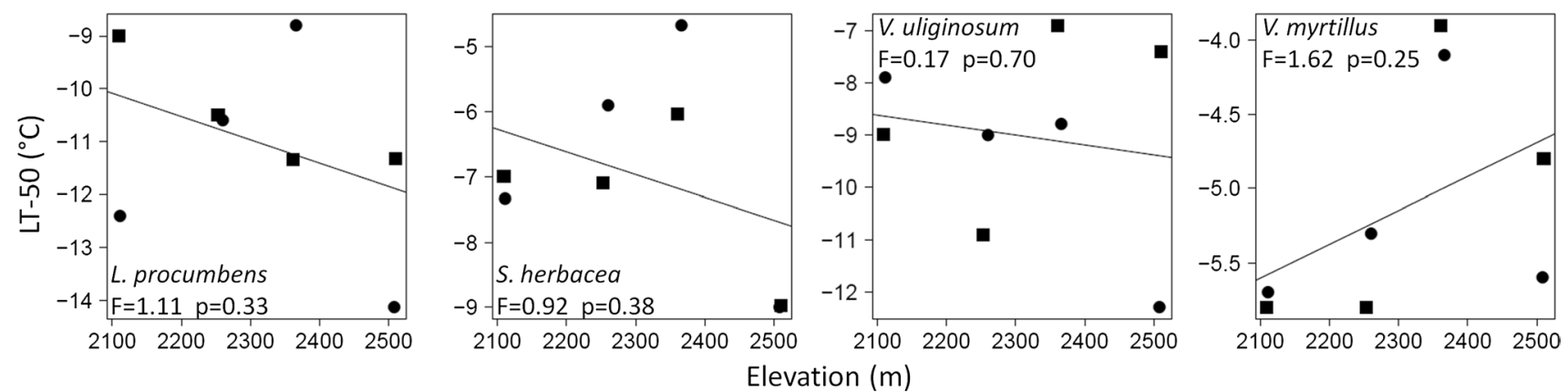

Fig. 3 Temperature at which $50 \%$ of specimens are killed (LT-50) along elevational gradient in $L$. procumbens, $S$. herbacea, $V$. uliginosum and V. myrtillus. Squares represent ridges and circles represent

snow bed microhabitats. $F$ - and $p$-values refer to the linear regressions for each species (black line). Note the different $y$-axes for the different species
Fig. 4 Modelled frequency of potentially lethal spring freezing events between 1975 and 2012 (37 years) for $V$. myrtillus in relation to year (a), elevation (b) and snowmelt day (c)

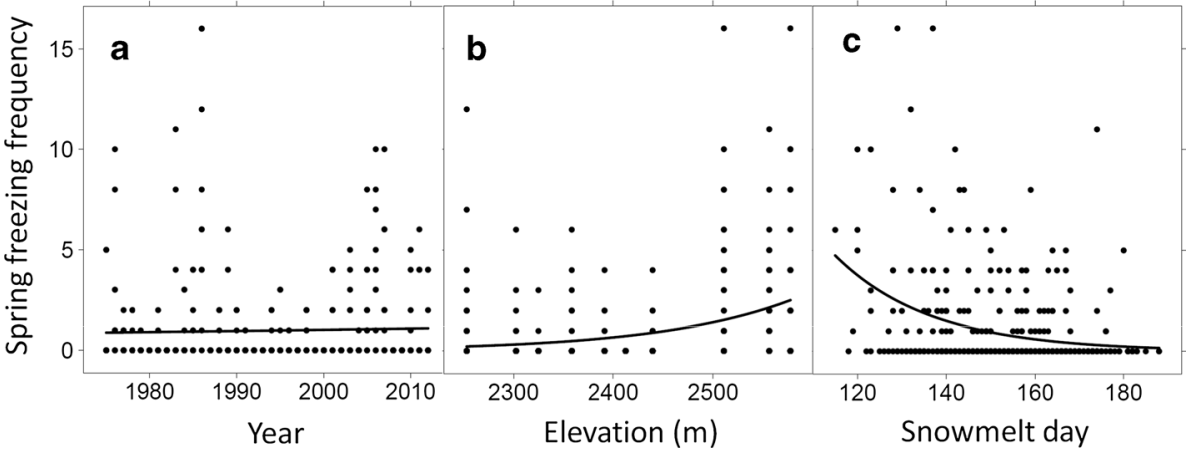


significant (Fig. $4 \mathrm{a} ; t=-0.60, p=0.55$ ). Thus, considering the significant increase in local air temperature over the same period of time $\left[0.58{ }^{\circ} \mathrm{C}\right.$ summer warming per decade since 1975 (Rixen et al. 2012)], our study counterintuitively suggests that warming spring air temperatures are not reducing the number of damaging spring freezing events. When lethal spring cold events are pooled across all years, V. myrtillus is at significantly increased risk of exposure with both increasing elevation (Fig. $4 \mathrm{~b} ; t=6.89$, $p<0.0001$ ) and earlier snowmelt (Fig. $4 \mathrm{c} ; t=-7.16$, $p<0.0001$ ), coupled with significant interactive effects $(t=3.58, p=0.00038)$, with high-elevation early exposed ridge habitats being the most vulnerable to freezing exposure.

Supplemental Table 1 lists all model variables, $F$-, $t$ - and $p$-values (Online Resource 1).

\section{Discussion}

In our alpine system, localized microhabitat effects were the primary drivers of snowmelt. Alpine dwarf shrub growth was not enhanced by natural early snowmelt, and different species at leaf maturity demonstrated significant differences in vulnerability to spring freezing exposure along the snowmelt and elevational gradient. Because freezing resistance at leaf maturity within a species did not change with elevation or microhabitat, both higher elevation and earlier snowmelt microhabitats had a significantly higher risk of spring freezing exposure. Spring freezing events increased slightly, although not significantly, over 37 years despite local warming spring air temperatures.

Growth performance along environmental gradients

Non-prostrate shrubs (V. myrtillus and V. uliginosum) demonstrated a significant elevational growth response in this study. This represents either a true growth response or different resource allocation patterns along the environmental gradient (Sakai et al. 2003). True growth including below-ground biomass production can often not be accurately determined in clonal alpine shrubs (Körner 2003). However, numerous studies have shown that vegetative above-ground structure size, such as shrub height, leaf size or stem length, is a practical variable for plant and community level responses (Hudson et al. 2011; Elmendorf et al. 2012). In our set of species, it is likely that shrub stature plays a major role in this observed growth response to elevation. Taller shrubs, like V. myrtillus and V. uliginosum, are more closely coupled to elevationally lapsed atmospheric temperatures (similar to arborescent species), whereas prostrate shrubs may be largely decoupled from free atmospheric conditions, and are likely more strongly exposed to and controlled by microclimatic conditions (Körner 2012). Consequently, fluctuations in air temperature are also more pronounced for taller shrubs, as prostrate species likely profit from delayed night heat loss due to the heat retention capacity of the soil and litter layers (Sakai and Larcher 1987; Körner 2003).

We found no evidence of enhanced shrub growth as a response to earlier snowmelt timing and thus a longer growing season, and there is increasing evidence in the literature that suggests a longer growing season does not necessarily benefit alpine plant growth. Although Mallik et al. (2011) demonstrated reduced growth in the Arctic shrub Cassiope tetragona under delayed snowmelt conditions, and $S$. herbacea has demonstrated natural increased growth under longer growing seasons (Wijk 1986), a review by Wipf and Rixen (2010) examining growth responses in snow manipulation experiments indicated no clear plant growth response pattern to delayed snowmelt. They suggested instead that responses depended on functional group, studied microhabitat type, and the magnitude of snowmelt timing change. The same review concluded that alpine plant growth responses to earlier snowmelt have been understudied (Wipf and Rixen 2010). Conifer tree species at and above tree line do not demonstrate strong growth responses to snowmelt timing (Barbeito et al. 2012), and in the few experimentally accelerated snowmelt studies, very few species demonstrated enhanced growth, with only Empetrum nigrum and $L$. procumbens, two species characteristic to snow-poor microsites, showing increased stem elongation in response to earlier snowmelt (Wipf et al. 2009; Wipf 2010). Gerdol et al. (2013) even demonstrated reduced growth in $V$. myrtillus under advanced snowmelt conditions. This prevailing lack of enhanced shrub growth, in both this and other studies, may be explained by the nature of temperature accumulation on ridge and snow bed microhabitat sites. Ridge sites emerge from snow earlier, and thus begin accumulating temperature earlier, but have lower seasonlong temperature means than late snowmelt microsites. As such, shrub communities growing on early snow-free sites have longer growing seasons with greater early season temperature sums, but colder mean temperatures and greater likelihood of exposure to spring cold events (Inouye 2008; Wipf et al. 2009; Gerdol et al. 2013). These spring cold events, occurring during active growth phases (i.e. development and maturation of leaf tissue) have the potential to severely damage plant biomass and can potentially limit new growth (Wipf et al. 2009; Sierra-Almeida and Cavieres 2012).

\section{Spring freezing resistance}

Freezing resistance was found to be species-specific and consistent with the existing literature for the shrub species 
examined (Taschler and Neuner 2004; Martin et al. 2010), although LT-50 dependence on the phenophase makes comparisons across studies difficult (Sakai and Larcher 1987; Lenz et al. 2013). Measured freezing resistance also corresponded roughly to ecological niche for each species, with prostrate, ridge-specialist evergreen $L$. procumbens having a higher freezing resistance than prostrate deciduous snow bed specialist $S$. herbacea or taller-growing, ubiquitous $V$. myrtillus. This corresponds with Bannister et al. (2005), who linked freezing resistance to microhabitat type, with snow bed and sheltered species having poorer frost resistance than early exposed ridge species. V. uliginosum fell outside this trend, but its higher freezing resistance compared to V. myrtillus was consistent with the literature (Taschler and Neuner 2004; Martin et al. 2010). Prostrate shrubs did not necessarily have greater freezing resistance than taller species in our study, corresponding to previous findings that found no correlation between species height and freezing resistance in temperate alpine and Ecuadorian páramo species (Taschler and Neuner 2004; Sklenar et al. 2010).

At time of sampling, freezing resistance was likely at a low point for each species in the spring period, as mature xylem and adult leaves have a lower freezing resistance than post-winter buds (Sakai and Larcher 1987). In the current study, we only sampled newly mature leaves along the entire gradient in order to minimize bias on LT-50 by different leaf developmental stages between sites. Thus, we are drawing conclusions about the freezing vulnerability of mature leaves. Freezing resistance likely changed strongly earlier in the growing season, but after leaf maturity, freezing resistance will change to a much lesser extent, unless in response to an unusual freezing event; Venn et al. (2013) and Ladinig et al. (2013) demonstrated that foliar tissue and vegetative shoots generally maintain a relatively consistent frost resistance through the growing season. We did not find any significant differences in LT-50 of mature leaves between snow microhabitats or along the elevational gradient. Similarly, Bannister et al. (2005) also found no consistent difference in freezing resistance in alpine species exposed early in spring compared to the same species growing in later snow beds. While Taschler and Neuner (2004) found that, in species with similar growth forms, the ones with higher distribution limits had higher freezing resistance, others reported no strong or consistent evidence for elevational decrease in LT-50 in mature leaves of Swiss broadleaf trees, grasses, or other alpine species (Márquez et al. 2007; SierraAlmeida et al. 2009; Lenz unpublished data). This suggests that shrub freezing resistance at leaf maturity is not closely tied to environmental conditions. In temperate broadleaf trees, it has been suggested that some species delay flushing and development until late enough that freezing events are highly unlikely (Lenz et al. 2013). This is less likely to be the case in alpine shrubs, however, since bud-beak in these species is closely linked to snowmelt timing and not controlled by photoperiod or air temperatures before flushing (Sakai and Larcher 1987; Rixen et al. 2012).

Cold hardening may act as a mechanism for increasing plant resistance to freezing. Extreme cold hardening has been shown to occur in grass species primed at subzero temperatures for 4 or more days (Bykova and Sage 2012). This hardening, however, occurred under winter conditions, which may not accurately reflect the episodic nature of spring freezing events, which are unlikely to be preceded by a long period of sub-zero temperatures (Rixen et al. 2012). In spring, when alpine shrub Rhododendron ferrugineum was exposed to in situ freezing under field conditions at the tree line, some cold hardening occurred after 3 days. However, hardening in this shrub was demonstrated to be slowed by a combination of warm daytime temperatures $\left(+19^{\circ} \mathrm{C}\right)$ followed by night freezing (Neuner et al. 1999). This multi-day lag period prior to cold hardening, exacerbated by strong diurnal temperature differences and coupled with the episodic nature of spring freezing, suggests that shrubs in this study were not cold-hardened at the time of sampling. It also suggests that in the absence of prolonged cold spring temperatures, spring cold-hardening is unlikely to function as a mechanism of mature leaf tissue freezing resistance in alpine shrubs. Indeed, Venn et al. (2013) found no consistent evidence for cold hardening in leaf tissue of alpine plants during the growing season. In the current study, we did not find differences in freezing resistance along the elevational gradient or among microhabitats within a species, suggesting only a limited potential to change LT50 in mature leaves in late spring, in the absence of a prolonged freezing event.

The similarity in mature leaf freezing resistance for each species along the snowmelt and elevational gradient greatly simplifies assumptions about the shrub community's vulnerability to spring freezing events. Since mature leaf tissue LT50 was linked to species, and not microsite conditions, it can be assumed that, after emergence from snow cover, mature leaves of a given species are more or less equally vulnerable to spring freezing across the local species distribution range. Our results suggest that the upper distribution limits for these alpine shrub species may be at least partially determined by spring cold temperature tolerances. Low-statured tree seedlings are known to establish above their elevational limit in microhabitats that may regulate favourable growing temperatures (Sundqvist et al. 2008, Wheeler et al. 2011), and lower elevation shrubs have been shown to track summer and winter warming into higher elevation snow bed sites in Sweden (Kullman 2002), suggesting colder temperatures limit upper distributions. Since episodic cold events are common after snowmelt (Körner 2003) and tend to strike shrubs during vulnerable active growth stages (Sierra-Almeida et al. 2009), 
these are possibly one of the limiting factors that reduce shrub performance (Wipf et al. 2009) and could thus control higher shrub distribution.

\section{Risk of spring freezing events}

Vaccinum myrtillus faces a far greater risk of spring freezing than the rest of the dominant shrub community. This is determined by both its poor freezing resistance and ubiquitous presence in early exposure microsites. Since resistance to freezing after dehardening is considered a strong filter for alpine plant distribution (Körner 2003), this suggests that $V$. myrtillus opportunistically responds to the episodic nature of spring freezing in both its microhabitat selection and its ability to thrive in non-optimal microsites where freezing risk is high. This shrub has been observed germinating successfully at high-elevation sites and in other microhabitats where adults do not thrive (Auffret et al. 2010). As an argument towards its opportunism, V. myrtillus is known to be relatively responsive to environmental change: germination occurs significantly earlier with summer warming, bud break is significantly earlier and growth ring width increases with warming, particularly in hot summers (Milbau et al. 2009; Prieto et al. 2009; Rixen et al. 2010). As a result, however, it is also known to be negatively impacted by certain site selection: leaf expansion and flowering are reduced by freezing events, and freezing resistance is decreased under soil warming (Martin et al. 2010; Gerdol et al. 2013). Its plasticity and successful establishment on early exposure microsites, despite its poor resistance and thus high likelihood of exposure to leaflethal spring freezing, suggest $V$. myrtillus establishment and growth represent an opportunistic response to periodic favourable conditions. Spring freezing causes aboveground damage, especially to leaf tissue, but is generally thought not to kill the species or control its survival at the population level (Körner and Larcher 1988; Taschler and Neuner 2004); V. myrtillus has been shown to regenerate leaf tissue lost to spring freezing damage (Wipf et al. 2009). However, repeated freezing events, especially after leaf maturity, when shrubs have already invested significant resources in leaf development, could potentially irreparably damage the leaf crop. Repeated seasons of freezing could then fatally deplete stored resources (Molau 1997).

Spring freezing damage has been shown to occur in wood and leaf tissue of $V$. myrtillus and $V$. uliginosum at tree line below our elevation gradient (Anadon-Rosell, unpublished data; Rixen et al. 2012). It is thus very likely a factor at higher elevations, especially since microhabitat-driven snowmelt patterns expose many high-elevation ridges to snow at similar times or earlier than lower elevation sites. The temporal and spatial restriction of episodic cold events (which only occur in May and June on ridge microhabitats) is relevant, as it indicates that only certain shrub communities risk damage. This trend has been observed in alpine wild flowers and dwarf shrubs growing in early snowmelt sites: earlier snowmelt leads to greater frequency of spring freezing events and significant damage to buds and leaf tissues, damage that is not sustained by plants growing in later snowmelt microsites (Inouye 2008; Wipf et al. 2009). This is a critical point, as snowmelt timing is significantly advancing in this and many other alpine communities (e.g. Inouye 2000, 2008; Rixen et al. 2012), and despite local warming air temperatures over the multidecadal record (Rixen et al. 2012), there is no evidence that lethal freezing events are in decline. Indeed, our extrapolation of spring cold-event frequency may even be conservative, since it is determined from ambient air temperature, when radiative cooling is known to lower leaf surface temperatures by as much as $5 \mathrm{~K}$ on clear nights (Jordan and Smith 1995). Ultimately, however, this extrapolation illustrates the increasing risk of leaf damage with elevation, with earlier snowmelt, and to a lesser extent, through time. Wipf et al. (2009) referred to the paradox of a cold spring in a warmer world, which our results support: spring freezing events are not becoming rarer, and they may have a strong influence on individual shrub performance and thus community structure at high-elevation and early exposure sites. We can also speculate that ridge communities may continue to remain more vulnerable than snow bed communities, as there is evidence that climate warming accelerates snowmelt on ridge microsites, while late snow beds may remain relatively static (Kudo and Hirao 2006).

\section{Conclusion}

Earlier snowmelt is predicted in many alpine ecosystems, and this abiotic change has critical implications for shrub community performance. In this and other studies cited, a longer growing season, driven by accelerated snowmelt, both fails to enhance growth and increases the risk of exposure to damaging spring freezing events at leaf maturity. This suggests that the detrimental effects associated with an extended growing season may outweigh the benefits for some alpine shrub species. As snowmelt timing accelerates, spring freezing events, which are not in decline despite warming in this system, are likely to become more common, especially in high-elevation and early snowmelt communities.

Acknowledgments We wish to acknowledge and thank Armando Lenz (University of Basel) for assistance provided during the laboratory freezing experiments, Felix Prahl and Yves Bötsch for their help during field sampling, Guenther Klonner for data-extraction assistance, and two anonymous reviews for improvements to the manuscript. This project was made possible by funding from the Swiss National Science Foundation (Grant CRSI33_130409/1). 


\section{References}

Auffret AG, Meineri E, Bruun HH, Ejrnæs R, Graae BJ (2010) Ontogenetic niche shifts in three Vaccinium species on a subalpine mountain side. Plant Ecol Div 3:131-139

Bannister P, Maegli T, Dickinson KJM, Halloy SRP, Knight A, Lord JM, Mark AF, Spencer KL (2005) Will loss of snow cover during climatic warming expose New Zealand alpine plants to increased frost damage? Oecologia 144:245-256

Barbeito I, Dawes MA, Rixen C, Senn J, Bebi P (2012) Factors driving mortality and growth at treeline: a 30-year experiment of 92,000 conifers. Ecology 93:389-401

Bokhorst S, Bjerke JW, Bowles FW, Melillo J, Callaghan TV, Phoenix GK (2008) Impacts of extreme winter warming in the subArctic: growing season responses of dwarf shrub heathland. Glob Change Biol 14:2603-2612

Bykova O, Sage RF (2012) Winter cold tolerance and the geographic range separation of Bromus tectorum and Bromus rubens, two severe invasive species in North America. Glob Change Biol 18:3654-3663

Elmendorf SC, Henry GHR, Hollister RD, Bjork RG, BoulangerLapointe N, Cooper EJ, Cornelissen JHC, Day TA, Dorrepaal E, Elumeeva TG, Gill M, Gould WA, Harte J, Hik DS, Hofgaard A, Johnson DR, Johnstone JF, Jonsdottir IS, Jorgenson JC, Klanderud K, Klein JA, Koh S, Kudo G, Lara M, Levesque E, Magnusson B, May JL, Mercado-Diaz JA, Michelsen A, Molau U, Myers-Smith IH, Oberbauer SF, Onipchenko VG, Rixen C, Martin Schmidt N, Shaver GR, Spasojevic MJ, Porhallsdottir PE, Tolvanen A, Troxler T, Tweedie CE, Villareal S, Wahren C-H, Walker X, Webber PJ, Welker JM, Wipf S (2012) Plot-scale evidence of tundra vegetation change and links to recent summer warming. Nature Clim Change 2:453-457

Gerdol R, Siffi C, Iacumin P, Gualmini M, Tomaselli M (2013) Advanced snowmelt affects vegetative growth and sexual reproduction of Vaccinium myrtillus in a sub-alpine heath. J Veg Sci 24:569-579

Heide OM (2001) Photoperiodic control of dormancy in Sedum telephium and some other herbaceous perennial plants. Physiol Plant 113:332-337

Hudson JMG, Henry GHR, Cornwell WK (2011) Taller and larger: shifts in Arctic tundra leaf traits after 16 years of experimental warming. Glob Change Biol 17:1013-1021

Inouye DW (2000) The ecological and evolutionary significance of frost in the context of climate change. Ecol Lett 3:457-463

Inouye DW (2008) Effects of climate change on phenology, frost damage, and floral abundance of montane wildflowers. Ecology 89:353-362

IPCC (eds) (2007) Climate change 2007: the physical science basis. Contribution of Working Group I to the fourth assessment report of the Intergovernmental Panel on Climate Change. Cambridge Univ. Press

Jordan DN, Smith WK (1995) Microclimate factors influencing the frequency and duration of growth season frost for subalpine plants. Agric For Meteorol 77:17-30

Keller F, Körner C (2003) The role of photoperiodism in alpine plant development. Arct Antarct Alp Res 35:361-368

Kirchner M, Faus-Kessler T, Jakobi G, Leuchner M, Ries L, Scheel HE, Suppan P (2013) Altitudinal temperature lapse rates in an Alpine valley: trends and the influence of season and weather patterns. Int J Climatol 33:539-555

Kollas C (2013) Bioclimate and reproductive potential at the cold limit of European deciduous tree species. PhD Thesis, University of Basel

Körner C (2003) Alpine plant life: functional plant ecology of high mountain ecosystems. Springer, Heidelberg Berlin New York
Körner C (2012) Treelines will be understood once the functional difference between a tree and a shrub is. Ambio 41:197-206

Körner C, Larcher W (1988) Plant life in climate climates. Symp Soc Exp Biol 42:25-57

Kudo G, Hirao AS (2006) Habitat-specific responses in the flowering phenology and seed set of alpine plants to climate variation: implications for global-change impacts. Popul Ecol 48:49-58

Kullman L (2002) Rapid recent range-margin rise of tree and shrub species in the Swedish Scandes. J Ecol 90:68-77

Ladinig U, Hacker J, Neuner G, Wagner J (2013) How endangered is sexual reproduction of high-mountain plants by summer frosts? Frost resistance, frequency of frost events and risk assessment. Oecologia 171:743-760

Larcher W, Kainmüller C, Wagner J (2003) Physiological plant ecology: ecophysiology and stress physiology of functional groups. Springer, Heidelberg Berlin New York

Larcher W, Kainmüller C, Wagner J (2010) Survival types of high mountain plants under extreme temperatures. Flora 205:3-18

Lenz A, Hoch G, Vitasse Y, Körner C (2013) European deciduous trees exhibit similar safety margins against damage by spring freeze events along elevational gradients. New Phytol. 200:1166-1175

Mallik AU, Wdowiak JV, Cooper EJ (2011) Growth and reproductive responses of Cassiope tetragona, a circumpolar evergreen shrub, to experimentally delayed snowmelt. Arct Antarct Alp Res 43:404-409

Márquez EJ, Rada F, Fariñas MR (2007) Freezing tolerance in grasses along an altitudinal gradient in the Venezuelan Andes. Oecologia 150:393-397

Martin M, Gavazov K, Körner C, Hättenschwiler S, Rixen C (2010) Reduced early growing season freezing resistance in alpine treeline plants under elevated atmospheric $\mathrm{CO}_{2}$. Glob Change Biol 16:1057-1070

Milbau A, Graae BJ, Shevtsova A, Nijs I (2009) Effects of a warmer climate on seed germination in the subarctic. Ann Bot 104:287-296

Molau U (1997) Phenology and reproductive success in arctic plants: susceptibility to climate change. In: Oechel W, Callaghan T, Gilmanov T, Holten J, Maxwell B, Molau U, Sveinbjörnsson B (eds) Global change and arctic terrestrial ecosystems. Springer, New York, pp 153-170

Neuner G, Ambach D, Buchner O (1999) Readiness to frost harden during the dehardening period measured in situ in leaves of Rhododendron ferrugineum L. at the alpine timberline. Flora 194:289-296

Prieto P, Peñuelas J, Niinemets U, Ogaya R, Schmidt IK, Beier C, Tietema A, Sowerby A, Emmett BA, Láng EK, Kröel-Dulay G, Lhotsky B, Cesaraccio C, Pellizzaro G, de Dato G, Sirca C, Estiarte $M(2009)$ Changes in the onset of spring growth in shrubland species in response to experimental warming along a north-south gradient in Europe. Glob Ecol Biogeogr 18:473-484

Rixen C, Schwoerer C, Wipf S (2010) Winter climate change at different temporal scales in Vaccinium myrtillus, an Arctic and alpine dwarf shrub. Polar Res 29:85-94

Rixen C, Dawes MA, Wipf S, Hagedorn F (2012) Evidence of enhanced freezing damage in treeline plants during six years of $\mathrm{CO}_{2}$ enrichment and soil warming. Oikos 121:1532-1543

Sakai A, Larcher W (1987) Frost survival of plants: responses and adaptation to freezing stress. Springer, Berlin Heidelberg New York

Sakai A, Matsui K, Kabeya D, Sakai S (2003) Altitudinal variation in lifetime growth trajectory and reproductive schedule of a subalpine conifer, Abies mariesii. Evol Ecol Res 5:671-689

Schirmer M, Wirz V, Clifton A, Lehning M (2011) Persistence in intra-annual snow depth distribution. 1. Measurements and topographic control. Water Res Res 47 
Sierra-Almeida A, Cavieres LA (2012) Summer freezing resistance of high-elevation plant species changes with ontogeny. Environ Exp Bot 80:10-15

Sierra-Almeida A, Cavieres LA, Bravo LA (2009) Freezing resistance varies within the growing season and with elevation in highAndean species of central Chile. New Phytol 182:461-469

Sklenar P, Kucerova A, Macek P, Mackova J (2010) Does plant height determine the freezing resistance in the páramo plants? Aust Ecol 35:929-934

Sundqvist MK, Bjork RG, Molau U (2008) Establishment of boreal forest species in alpine dwarf-shrub heath in subarctic Sweden. Plant Ecol Div 1:67-75

Taschler D, Neuner G (2004) Summer frost resistance and freezing patterns measured in situ in leaves of major alpine plant growth forms in relation to their upper distribution boundary. Plant Cell Environ 27:737-746
Venn SE, Morgan JW, Lord JM (2013) Foliar freezing resistance of Australian alpine plants over the growing season. Aust Ecol 38:152-161

Wheeler JA, Hermanutz L, Marino PM (2011) Feathermoss seedbeds facilitate black spruce seedling recruitment in the forest-tundra ecotone (Labrador, Canada). Oikos 120:1263-1271

Wijk S (1986) Performance of Salix herbacea in an alpine snowbed gradient. J Ecol 74:675-684

Wipf S (2010) Phenology, growth, and fecundity of eight subarctic tundra species in response to snowmelt manipulations. Plant Ecol 207:53-66

Wipf S, Rixen C (2010) A review of snow manipulation experiments in Arctic and alpine tundra ecosystems. Polar Res 29:95-109

Wipf S, Stoeckli V, Bebi P (2009) Winter climate change in alpine tundra: plant responses to changes in snow depth and snowmelt timing. Clim Change 94:105-121 